\title{
電力管理システム導入による居住者の意識行動と消費量削減効果の分析 - 広島地域の全電化住宅を対象とした電力消費量に関する研究- \\ ANALYSIS OF THE CONSCIOUSNESS BEHAVIOR OF INHABITANTS AND REDUCTION EFFECT OF ENERGY CONSUMPTION BY SETTING-UP THE ENERGY MANAGEMENT SYSTEM
}

- Study on the energy consumption of electrified housing in Hiroshima area -

\section{安藤元気 ${ }^{*}$, 西名大作**, 村川三郎***, 石田正 樹**** \\ Motoki ANDO, Daisaku NISHINA, Saburo MURAKAWA and Masaki ISHIDA}

\begin{abstract}
The electric energy consumption of 100 electrified housing in Hiroshima area was measured by energy management system as one kind of HEMS. In this paper, on the basis of the comparison between the annual energy consumption before and after setting-up of the system, the reduction effect of installation of the system was clarified. As the results, the rate of reduction compared with the consumption before setting-up was approximately $3 \%$.

Furthermore, the factors of the reduction of energy consumption were examined. According to the comparison of three household groups classified by the consciousness and behavior of inhabitants, the reduction rate of the group which has already chosen the energy saving behavior before setting-up was larger than it of the group which tried to save the energy consumption after setting-up.
\end{abstract}

\author{
Keywords : Electrified housing, Energy Consumption, Land survey, Questionnaire, Energy Reduction Effect, \\ Visualization \\ 全電化住宅，電力消費量，実測調査，アンケート調査，削減効果，見える化
}

\section{1.はじめに}

世界規模での地球温暖化対策に向けて, エネルギー消費の抑制と， 効率的使用が，エネルギー資源の乏しい日本にとって喫緊の課題で あると同時に，先進国として課せられた使命となっており，国が掲 げる政策は，企業のみならず，個人レベルにおけるエネルギー消費 動向にまで波及している。一方, 技術の進歩に伴う生活水準の向上 から, 個人を取り巻く環境は劇的に変化しており, 年々増加傾向に ある民生用家庭部門のエネルギー消費削減が重要な課題となってお り, 住宅の断熱性能の向上, 省エネ家電機器や高効率照明の開発な どハード面における技術革新がなお一層進められている。また，東 日本大震災以降, 従来から知られている太陽光発電システムに加え て, エネルギーの貯蔵が可能な蓄電池システムや, 住宅設備や家電 製品が消費するエネルギーを賢く使うための HEMS (Home Energy Management System）を導入した「スマートハウス」が登 場し，今後における普及拡大が予想される。

このなかで，家庭でのエネルギー使用量を計測・表示する機能と 機器の使用量などを制限する機能を併せ持つ HEMS は, ソフト面 の対策であり，いわゆる「見える化」により居住者の意識向上や注 意喚起が期待できる。しかしながら, 実際に HEMS の導入によっ
て居住者が省エネ行動に至り，エネルギーが削減されているかどう かが明らかにされる必要があるが，この点についてはシステムの開 発普及に伴い，近年検討されているところではあるものの，未だデ ータが十分であるとはいえない。

そこで本研究では，視覚的にエネルギー消費動向を把握すること が可能である中国電力株式会社が開発した HEMS の一種といえる 「光熱費管理支援システム」が設置された電化住宅を対象として, 「見える化」による意識喚起がエネルギー消費量の削減に及ぼす効 果について検討することを目的とする。すなわち，システム設置前 の 1 年間と設置後の 1 年間の電力消費量を比較して，前者に基づく 後者の増減率を示すことで, その効果量と省エネ不行動（節約行為） との関連分析を行ったうえで, 削減に至る背景要因について居住者 の本システムに対する意識や環境に配慮した意識との関連から解明 する。

これまでの多くの研究により, 住宅でのエネルギー消費量は, 外 気温, 建物特性, 世帯特性, 保有家電機器特性, ライフスタイル, 居住者の意識や行動など様々な要因の影響を受けることが知られて おり，居住者の省エネ意識や節約行為が電力消費量に与える影響に ついても検討が進められている。森ら ${ }^{11}$ は戸建住宅を対象にエネル
* 広島大学大学院工学研究科 博十後期課程 · 修十 (工学)

**広島大学大学院工学研究科 教授. 博士 (工学)

***広島大学サステナブル・ディベロップメント 実践研究センター 特任教授・工博

**** 広島大学大学院工学研究科 博士前期課程
Graduate Student, Graduate School of Engineering, Hiroshima Univ., M. Eng.

Prof., Graduate School of Engineering, Hiroshima Univ., Dr. Eng.

Prof. Special Appointment, The Institute for Sustainable Science and Development,

Hiroshima Univ., Dr. Eng.

Graduate Student, Graduate School of Engineering, Hiroshima Univ. 
ギー消費量や節約行為に関するアンケート調查により, 節約行為に よる省エネルギー効果の考察を行っており, 水谷ら 2) は用途ごとの エネルギー消費量と住まい方との関係について分析を行った結果, 両者に明確な相関がみられることや省エネに努めている世帯のエネ ルギー消費量が少ないことなどを示している。湯淺ら 3)は低負荷型 ライフスタイルのエネルギー消費量を 1 週間実測し, 平常時との比 較検討から，エネルギー削減の可能性を明らかにしている。しかし ながら, いずれの研究も, 居住者の意識や行動がエネルギー消費量 に及ぼす影響について検討しているものの, エネルギー消費を視覚 的に把握することにより省エネ・節約行為が㬇起されたものとはな っていない。

また, HEMS の導入による省エネルギー効果を検証した研究とし ては, 石田ら ${ }^{4}$ による, エアコンと照明を対象とした在・不在制御 による検証例があるものの, 「自動制御」による効果を主眼としてお り，居住者意識には着目していない。一方，畑ら 5)は，居住者の節 電行動実践度による消費傾向の差異について検討しており, 実践度 の高低が消費電力と関連し, 環境エネルギー情報表示システムが節 電行動の促進に効果的であることを示している。しかしながら，シ ステム導入以前の消費傾向については示されておらず，見える化に よる削減効果については明らかとなっていない。

本研究は, 広島市内ならびにその周辺という限定された地域に所 在する多数の電化住宅を対象に, HEMSにより視覚的に促された意 識喚起の効果について明らかにするとともに, システム導入を契機 とした居住者の意識・行動の変化が及ぼす影響に着目して分析を行 う。

\section{2. 調査概要}

\section{1 測定概要}

光熱費管理支援システム（以降,「システム」と称する）は, 電化 住宅特約の契約住宅を対象としたダイレクトメールおよび電話によ るモニター募集に応募し, 選定された 100 件の住宅に設置されてい る注1)。所在地は, 広島市が 99 件, 廿日市市が 1 件で, 本研究では, 住宅形式が戸建て住宅である 98 件を対象としている。システムは 2008 年 6 月から順次取り付けを開始し, 2008 年 10 月には全住宅 への取り付けが完了している。

システムの機器構成を図 1 に示す。住宅全体と居住者の要望によ り選択された 10 系統の計 11 系統の電力消費量が, 住宅の屋内分電 盤に隣接して取り付けられた計測装置によって測定されており, ホ ームゲートウェイに接続された居住者所有のルータを介して, デー タサーバーに送信され，そこで蓄積・管理される。居住者は所有の パソコンからインターネットを介してサーバーにアクセスし, 現在 や過去の電力消費量を専用のホームページで確認することが可能で ある注2)

\section{2 アンケート調査概要}

調査対象住宅の建物特性や世帯特性, 居住者の環境問題に対する 意識や節約行為の実行状況などを把握するため, 居住者を対象とし てアンケート調査を実施した(以降, これを「属性調查」と称する)。 また，中国電力株でも，システムの利用状況や評価に関するアンケ ートである「モニター調査」を 2 回にわたり実施している。 各アンケート調查内容を表 1 に示す。

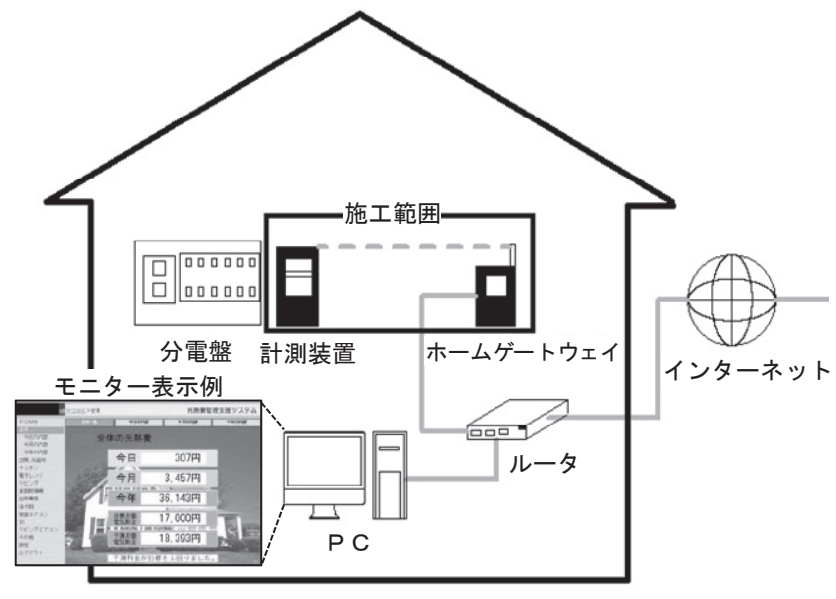

図 1 機器構成図

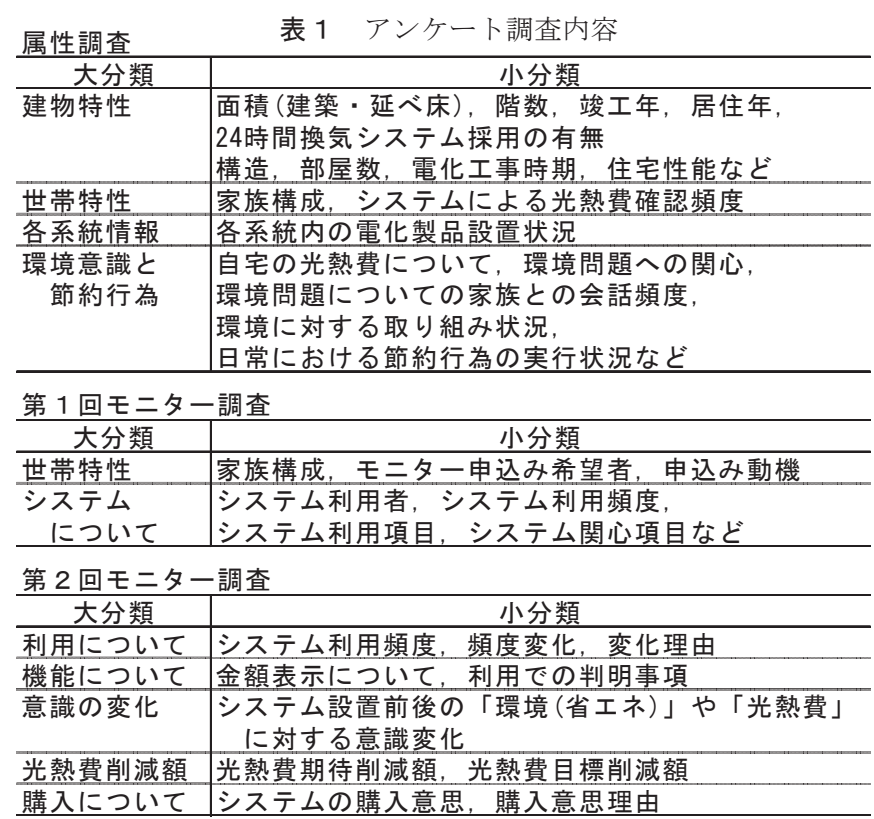

「属性調查」は 2008 年 12 月中旬〜下旬, 「モニター調查」の第 1 回はシステム設置直後である 2008 年 10 月上旬 11 月下旬，第 2 回は 2008 年 12 月中旬 1 月中旬にかけて実施しており, 配布数 100 件に対し, 回収数はそれぞれ 78 件，93 件，88 件である注3)。

\section{3 検針值の概要}

システム設置による効果を検証するためには，システム設置前の 電力消費量が必要であるため, 本研究では光熱費管理支援システム による「測定值」の他に，電力事業者が実施する定期的な検針によ る「検針值」も分析の対象としている。検針值のデータ提供期間は, システムの設置が開始された 2008 年 6 月の 1 年以上前にあたる $\lceil 2007$ 年 2 月」から, 設置後 1 年以上経過した「 2009 年 11 月」 までである。検針值の提供世帯数は,「属性調査」内でデー夕提供に ついて了承が得られた 73 件であるが, システム設置前後の各 1 年 間の值に久測等がある世帯を除く 66 件を，消費量削減効果を検討 する際の分析対象世帯としている。なお, 検針值の測定精度は $1 \mathrm{kWh}$ 単位で, 測定間隔は月単位であるが, 住宅によって検針日が異なり, 同じ月でも検針值の測定期間は世帯間でずれが存在する。したがっ て, 本研究では世帯間の誤差が小さくなるよう, 設置前後の比較に は年間ベースの電力消費量を用いる。 

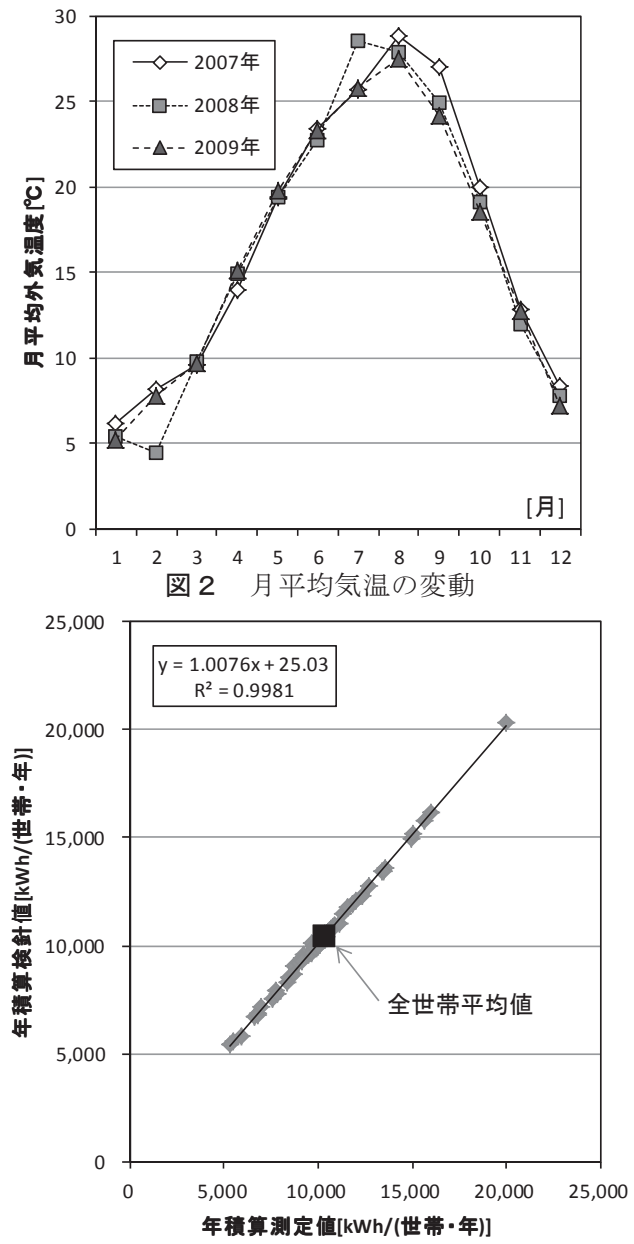

図 3 年積算電力消費量の比較

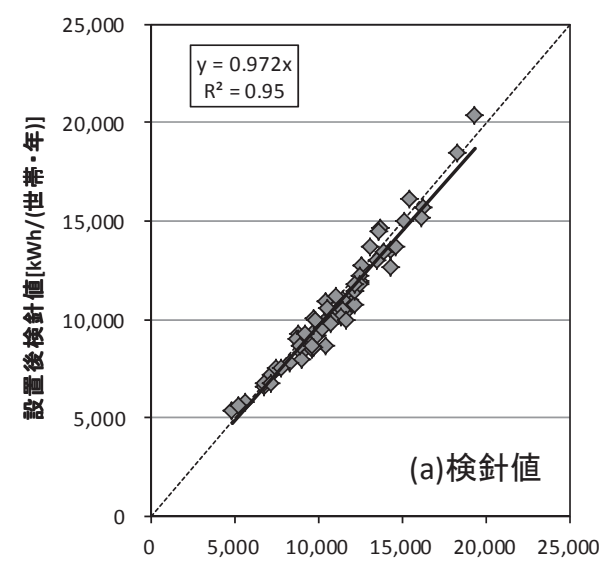

設置前検針値 $[\mathrm{kWh} /$ (世帯·年)]

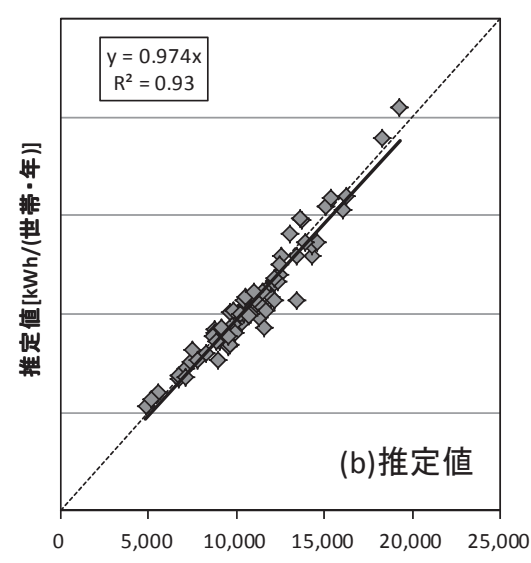

設置前検針値[kWh/(世帯·年)]

図 4 設置前検針值と設置後検針值・推定值の比較
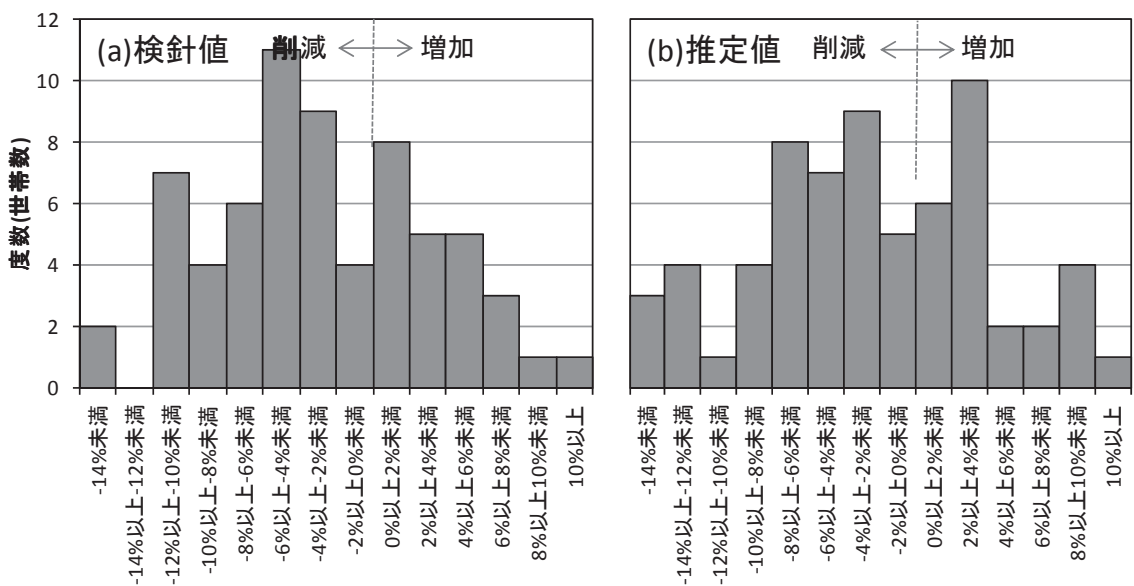

図 5 増減率の度数分布

\section{4 気象概要}

本研究で対象とする住宅の所在地である広島県広島市周辺は, 県 南西部に位置しており, 年間を通して日照時間が長く, 比較的温暖 な傾向を示し, 中国山地と四国山地に挟まれた瀬戸内圈の気候的特 徵を有する地域である。設置前後の各 1 年の電力消費量を比較する 場合, システム設置による意識・行動の変化に加え, 気象条件が冷 暖房に及ぼす影響も大きいことから，ここでは検討対象とする時期 の気象概要について整理する。

広島地方気象台で観測されたシステム設置前の 2007 年からの 3 年間における月平均気温の変動を図 2 に示す。これより, システム 設置が完了した 2008 年 11 月以降を設置前と比較すると, 2 月に高 温, 7 月に低温が観測されているが, 他の月においてはほとんど差 のないことがわかる。

\section{3．システム導入による削減効果}

本章では, システム設置前後の各 1 年間における電力消費量を比 較するにあたって, 検針值の精度の妥当性について, システムによ る測定值との対応関係を確認したうえで,「増減率」を算出し, 電力 消費量の削減効果について検討寸る。

\section{1 全電化住宅における電力消費量}

全電化住宅における電力消費量を把握するため, システムによっ て計測された「 2008 年 10 月〜 2009 年 9 月」の 1 年間の測定值に 基づく積算值を，同期間における検針值と併せて図 3 に示す。
これより, 測定值による平均年積算電力消費量は $10,352[\mathrm{kWh} /$ (世 帯・年) となり，検針值 $10,453[\mathrm{kWh} /$ (世帯・年) $]$ と比較しても，ほ ぼ同じ值であることがわかる。検針值は $\mathrm{kWh}$ 単位と精度は粗いも のの，年間ベースでの検討では，精度が高い測定值と対応がとれて いることが確認できる。

\section{2 設置前後の電力消費量の比較}

システム導入による電力消費量の削減効果を検討寸るため, 検針 值に基づいた設置前後の年積算電力消費量を比較する注 4)。しかし, 検針值にはシステム導入による削減効果に加え，気象条件の影響が 含まれる。そこで, 設置後のシステムによる測定值を用いて，世帯 ごとの日積算電力消費量 $(\mathrm{y})$ と日平均外気温 $(\mathrm{x})$ の関係式注 5$)$ $\left(\mathrm{y}=\mathrm{ax}^{2-\mathrm{bx}}+\mathrm{c}\right)$ を求め, 上式の $\mathrm{x}$ に設置前の日平均外気温を代入する ことで推定日積算電力消費量を求め, それらの総和から外気温の影 響を除外した世帯ごとの推定年積算值を算出した注 6)。この值は, シ ステム設置後に変化した意識・行動の下で, 設置前の気象条件で過 ごした場合の電力消費量の「推定值」となる。

設置後の「(a)検針值」と「(b)推定值」のそれぞれを，設置前の「検 針值」と比較した結果を図 4 に示す。

回帰直線の傾きは，(a)が約 0.972，(b)が約 0.974 で，およそ $3 \%$ 減となっている。設置前後の值を用いて, 対応のあるサンプルの $\mathrm{t}$ 一検定を実施した結果，設置後が設置前に比べ，(a)・(b) ともに $1 \%$ 水準で有意に小さいことが確認できた。設置前の 1 年間と比べ，設 置後は暖冬・冷夏であったことから, 冷暖房電力消費量の低下が予 


\begin{tabular}{|c|c|c|c|}
\hline \multirow[b]{2}{*}{ 分類 } & \multirow[b]{2}{*}{ 低負荷型ライフスタイル } & \multicolumn{2}{|l|}{ 実行度 } \\
\hline & & していない & $\begin{array}{l}\text { 検定 } \\
\text { 結里 }\end{array}$ \\
\hline \multirow{6}{*}{ 空調 } & 【暖冷房(1)】 冷 (暖) 房する時間や期間を減らす & 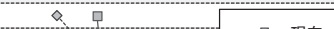 & $* * *$ \\
\hline & 【暖冷房(2】 冷 (暖)房する部屋の数を減らす & 一正現在 & $* * *$ \\
\hline & 【暖冷房(3】冷(䁔)房の設定温度を高(低)めにする & ........慢来 & $* * *$ \\
\hline & 【暖冷房(4)】こまめにフィルターを掃除する & $\cdots \diamond \cdots$ 将来 & **** \\
\hline & 【暖冷房(5)】冷房時に扇風機を併用する & $\infty<$ & $* * *$ \\
\hline & 【暖冷房6】なるベく服装で調整する & $\alpha<\alpha$ & $* * *$ \\
\hline \multirow{11}{*}{ 䐚房 } & 【調理(1) 下ごしらえは電子レンジを活用する & $\infty>0$ & $* * *$ \\
\hline & [調理(2) 段取りよく調理する & $\alpha<<$ & $* * *$ \\
\hline & 【掵蔵庫(1)】季節に合わせて設定温度を調整する & $8>$ & $* * *$ \\
\hline & 【冷蔵庫(2】ドアの開閉を少なく手早くする & 8 & $* * *$ \\
\hline & 【椧蔵庫(3) 物を詰め込みすきないようにする & $\infty \quad-6$ & $* * *$ \\
\hline & 【桧蔵庫(4)】熱いものは常温で泠やしてから入れる & 8 & $* * *$ \\
\hline & 【食洗機(1】 まとめて洗う & $\alpha \varepsilon$ & ** \\
\hline & 【食洗機(2】設定温度を調節する & & $* * *$ \\
\hline & 【食洗機(3】 標㲚（節約) コースで洗う & $\Delta[0 \quad-\quad 2$ & ** \\
\hline & 【炊事(1)】食器洗いの際の湯温を低くする & \multirow{2}{*}{8} & $* * *$ \\
\hline & 【炊事(2)】 洗い物はため洗いをする & & $* * *$ \\
\hline \multirow{6}{*}{ 給湯 } & 【風呂(1)】家族が入浴時間を合わせて入浴している & 81 & $* * *$ \\
\hline & 【風呂(2) 風呂のお湯の使用量を減らす & 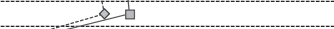 & $* * *$ \\
\hline & 【風呂(3】入浴後は浴棤にフタをする & $\infty$ & \\
\hline & 【洗面(1) お湯の使用時間を短くする & 89 & $* * *$ \\
\hline & 【洗面(2】お湯の設定温度を低くする & \multirow[t]{2}{*}{$8 \ldots$} & $* * *$ \\
\hline & 【洗面(3) 温水を使わない & & $* * *$ \\
\hline \multirow{10}{*}{ その他 } & 【洗便座(1)】使用しないときはフタを閉める & $8 \mathrm{OB}=$ & $* * *$ \\
\hline & 【洗便座(2)】季節に合わせて設定温度を調整する & 80 & $* * *$ \\
\hline & 【洗䍜機(1)】使用時にまとめ洗いをする & $\alpha 2-\alpha$ & $* * *$ \\
\hline & 【洗湌機(2】 風呂の残り湯を使用する & \multirow{2}{*}{$a_{a}$} & * \\
\hline & 【洗濯機(3】 軽い污れは短時間で洗うコースを使用する & & $* * *$ \\
\hline & 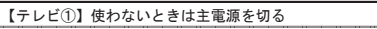 & $\diamond$ & $* * *$ \\
\hline & 【テレビ(2)】 使用時間を短くする & $\infty \quad 6$ & $* * *$ \\
\hline & 【パソコン】省エネモードにする & $\infty \quad 0$ & $* * *$ \\
\hline & 【照明(1)】 使用していない部屋の照明は消す & $\alpha$ & \\
\hline & 【照明(2】 家族が同じ部屋で団らんする & $\infty$ & \\
\hline
\end{tabular}

図 6 節約行為の世帯平均実行度

想されるが,「(b)推定值」による外気温の影響を除外した場合でも， システム導入による一定の削減効果が認められることがわかる。

\section{3 世帯ごとの削減効果}

設置前検針值に対する(a)設置後検針值または(b)推定值の電力消 費量の差の割合を「増減率[\%]」として, 世帯ごとに求めた度数分布 を図 5 に示す。

システム設置後に電力消費量が削減されている世帯の全世帯に対 する割合は，(a)で約 $65 \% ，(b)$ で約 $62 \%$ となり，いずれの場合にお いても削減されている世帯が半数以上を占めている。設置後に増加 あるいは減少した世帯の割合が等しいことを帰無仮説として $x^{2}$ 検 定を実施した結果，(a) ・ (b) ともに削減した世帯数が 5 \%水準で有意 に多いことが確認できた。

これまでの結果から,「検針值」と「推定值」にほぼ同様の傾向が みられ, 大きな違いがないこと,「推定值」には予測式の推定による 誤差が含まれることを勘案し, 以降では, システム導入による効果 を検討する際の電力消費量データとして「(a)検針值」を用いること とする。

\section{4. 節約行為と増減率の関連}

増減率はシステム導入を契機とした居住者の行動の変化が反映さ れた結果の一端であると考えられる。電力消費量の増減に大きな影 響を及ぼす居住者の行動として, 日常的に行う「節約行為」が挙げ られる。そこで本章では, 増減率に影響を及ぼす要因を抽出するた めに, アンケート調查における節約行為の単純集計結果を示したう えで，増減率との関連を整理する。

\section{1 節約行為の実行状況と節約意欲}

属性調查では, 居住者の節約行為の実行度について, 33 項目の行 為それぞれの「現在（システム設置前）の実行状況」と「近い将来 (システム設置後）における予想実行度」について尋㱛ている注7)。

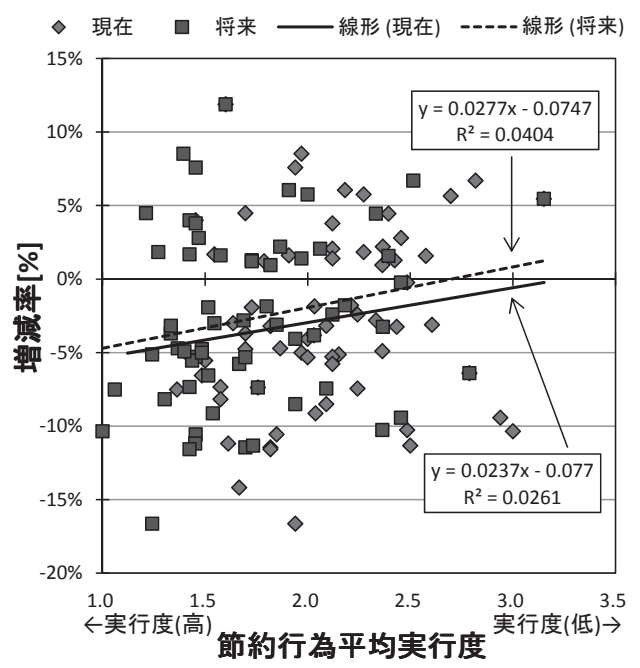

図 7 節約行為平均実行度と増減率の関連

現在と将来のそれぞれにおける実行度の全世帯平均值を図 6 に示 す。

現在の実行度では，「【食洗機(1)】まとめて洗う」「風呂(3】入浴 後は浴槽にフタをする」「洗濯機(1】使用時にまとめ洗いをする」 「照明(1)】使用していない部屋の照明は消寸」などは比較的容易な 行為であるため, 実行度が高い一方で, 「冷蔵庫(1】季節に合わせ て設定温度を調整する」「食洗機(2)】設定温度を調節する」などの 手間がかかるものや「洗面(3】温水を使わない」「「レビ(2)】使用 時間を短くする」などの快適性を損なうものについては低くなる傾 向にある。

将来の予想実行度は，全ての項目において現在の実行度を上回っ ている。両者における $\mathrm{t}$ 一検定結果をみると，すでに現在の実行度 が非常に高い「風呂(3)入浴後は浴槽につタをする」や照明関係で は, 将来の予想実行度との差異はみられないものの, ほとんどの項 目において有意差が認められることから，多くの世帯において，シ ステム設置を契機として節約行為が促進される期待感が高まってい るものと予想される。

\section{2 各項目が増減率に及ぼす影響}

現在と将来における 33 項目の節約行為の各世帯平均実行度と増 減率の関連を図 7 に示寸。

両者に高い相関関係は認められないが，現在・将来ともに実行度 が高い世帯ほど増減率が小となり，削減傾向にあることがわかる。 また，現在と将来を比較すると，後者のほうがわずかながら決定係 数が高いことからも，システム設置を契機とした行動の変化が電力 消費量削減の一因と考えられる。

そこで, 現在と将来の実行度の変化に着目して, 項目ごとに世帯 を3つのグループに分類する。具体的には, 現在よりも将来の実行 度を高く選択した世帯とそうではない世帯に分け，前者を「節約意 欲向上世帯」, 後者を「現状維持世帯」とし, さらに後者については, 将来の予想実行度で「していると思う」を選択した世帯を「現状維 持 (高実行度) 世帯」,「していると思う」以外を選択した世帯を「現 状維持（低実行度）世帯」とする。

節約行為の各項目におけるグループ間の増減率の差異についての 分散分析結果と, 各グループの平均増減率を表 2 に示す。なお, こ 


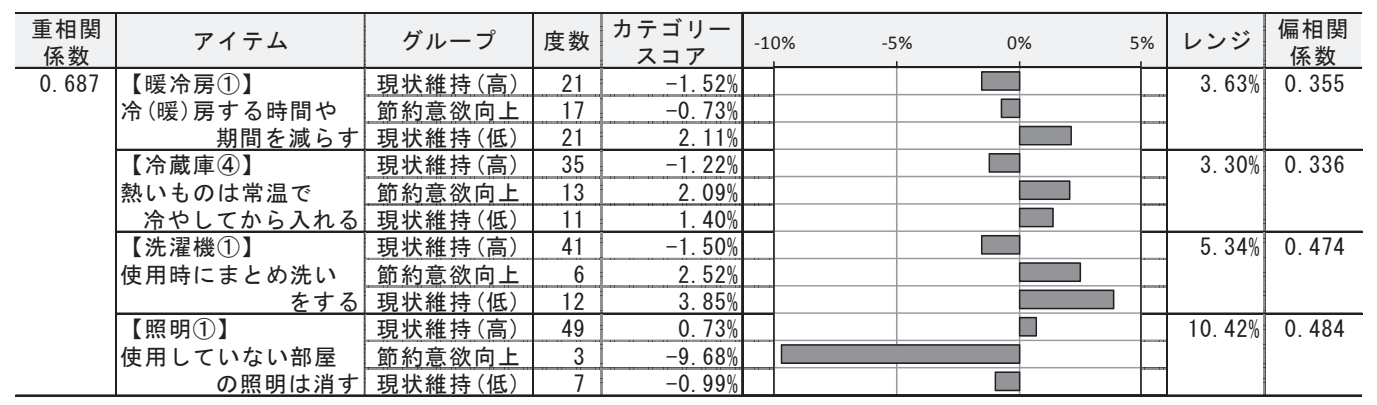

図 8 数量化理論第 I 類による分析結果
に節約行為が実行されることが 期待されたものの, 実際の生活 習慣にまでは定着しなかったも のと推察され, システムによっ て感化され, より節約が促進さ れた「現状維持(高実行度)世帯」 ほど，削減されなかったものと 考えられる。

一方，【照明(1)【は, 各グルー プのサンプル数に偏りがあるた
表 2 グループごとの増減率と分散分析検定結果

\begin{tabular}{|c|c|c|c|c|c|c|c|c|}
\hline & アイテム & グループ & 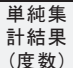 & $\begin{array}{c}\text { グループ } \\
\text { ごとの } \\
\text { 増減率 }\end{array}$ & & $\begin{array}{l}\text { グル } \\
\text {-プ } \\
1\end{array}$ & $\begin{array}{c}\text { グル } \\
\text {-プ } \\
2\end{array}$ & 増減率 \\
\hline & 【暖冷房(1】 & & & & & 分散分 & 析結果 & ** \\
\hline & 冷 (暖) 房する時間や & (1) 現状維持 (高) & 24 & $-4.81 \%$ & 搰 & (1) & (2) & \\
\hline & 期間を減らす & (2) 節約意欲向上 & 22 & $-3.55 \%$ & 新 & & (3) & ** \\
\hline & & (3) 現状維持 (低) & 24 & $-0.06 \%$ & 保 & (2) & (3) & \\
\hline & 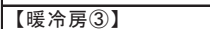 & & & & & 分散分 & 析結果 & * \\
\hline & 冷 (暖) 房の設定温度 & (1) 現状維持 (高) & 27 & $-4.43 \%$ & 榾 & (1) & (2) & \\
\hline & を高(低)めにする & (2) 節約意欲向上 & 23 & $-2.82 \%$ & 笽 & & (3) & * \\
\hline & & (3) 現状維持 (低) & 21 & $-0.54 \%$ & 像 & (2) & (3) & \\
\hline & 【冷蔵庫(4)】 & & & & & 分散分 & 析結果 & ** \\
\hline & 熱いものは常温で & (1) 現状維持 (高) & 45 & $-4.02 \%$ & 嫶 & (1) & (2) & \\
\hline & 冷やしてから入れる & (2) 節約意欲向上 & 14 & $-1.29 \%$ & 要 & & (3) & * \\
\hline 姁 & & (3) 現状維持 (低) & 13 & $0.50 \%$ & 略 & (2) & (3) & \\
\hline & \begin{tabular}{|l|} 
【洗濯機(1)】 \\
\end{tabular} & & & & & 分散分 & 析結果 & $* * *$ \\
\hline & 使用時にまとめ洗い & (1) 現状維持 (高) & 52 & $-4.07 \%$ & 莶 & $(1)$ & (2) & $*$ \\
\hline & をする & (2) 節約意欲向上 & 8 & $1.46 \%$ & 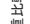 & & (3) & ** \\
\hline & & (3) 現状維持 (低) & 12 & $0.90 \%$ & 酯 & (2) & (3) & \\
\hline & $\mid$\begin{tabular}{|l|} 
【照明(1)】 \\
\end{tabular} & & & & & 分散分 & 析結果 & **** \\
\hline & 使用していない部屋 & (1) 現状維持 (高) & 60 & $-2.36 \%$ & 搰 & (1) & (2) & ** \\
\hline & の照明は消す & (2) 節約意欲向上 & 4 & $-10.97 \%$ & + & & (3) & \\
\hline & & (3) 現状維持 (低) & 9 & $-0.29 \%$ & 保 & (2) & (3) & **** \\
\hline
\end{tabular}

こでは節約行為 33 項目のうち, 分散分析において $10 \%$ 水準で有意 な項目のみを掲載している。また, 分散分析結果が有意な場合, 同 表にはグループ間の多重比較検定結果も併せて示す。

分散分析の結果, $5 \%$ 水準で有意差が認められるのは, 「【暖冷房 (1)】冷(暖)房する時間や期間を減らす」「冷蔵庫(4)】熱いものは常 温で泠やしてから入れる」「洗濯機(1)使用時にまとめ洗いをする」

「照明(1)使用していない部屋の照明は消す」の４項目にとどま る。多重比較検定結果から【照明(1)】を除く 3 項目では「現状維持 (高実行度)世帯」と「現状維持(低実行度)世帯」の間で差異が大きく なっており，いずれも前者の削減が大となっている。

\section{5. 増減率に対する影響要因の検討}

本章では, 前章の結果を踏まえ, 電力消費量の増減に影響を及ぼ 寸要因を検討寸るために, 増減率を目的変数, 節約行為を説明変数 として, 数量化理論第 I 類を適用寸る。説明変数としては項目間の 相関係数注躬表 1) から多重共線性の影響を考慮し，表 2 において $5 \%$ 水準で有意だった 4 項目を選定した。

結果を図 8 に示す。

本モデルの重相関係数は 0.687 であり, 4 項目によって各世帯の 増減率の違いの約 $47 \%$ を説明できることがわかる。偏相関係数に着 目寸ると, 4 項目全てが 0.3 以上と比較的高いことから, それぞれ 影響力のある項目であるといえる。

【暖冷房(1)】【冷蔵庫(4)】洗濯機(1)】については「現状維持(高実 行度)世帯」がいずれの項目においても削減傾向にあり, 逆に「現状 維持(低実行度)世帯」は増加している。一方, 行動の変化により大 きな削減が見込まれる「節約意欲向上世帯」は「現状維持(高実行度) 世帯」を超える削減が認められない。これは, システム設置を契機
め，参考的な考察となるものの，4項目の中で最も高い偏相関係数 を示しており，特に「節約意欲向上世帯」に属する 3 世帯は 10\%程 度削減されている。4.1 節で示したように【照明(1)】は比較的容易 であるため，すでに多くの世帯で実行されており，未実施であった

「節約意欲向上世帯」が実践した結果が反映されたものであると考 えられる。照明のように消費電力が小さくても電源を入れると一定 の消費が継続されるような機器については, 不要な箇所の電力を断 つだけでも大きな節電効果が期待できることが示唆される。

\section{6. 行動背景要因としての意識的側面}

前章では，増減率に大きな影響を及ぼすと考えられる要因につい て, 行動的側面である節約行為実行状況の居住者自身による行動変 化予想から検討した結果，節約意欲が高い世帯よりも，システム設 置前から節約行為を実行している世帯でより削減される傾向がみら れた。居住者が自身の評価どおりに行動しているのであれば，節約 行為の実行度に変化がない現状維持世帯の増減率は小さく, 節約意 欲向上世帯の削減が大となることが予想されるが，そのような結果 にはなっていない。これは, システム設置直後のアンケート調査時 点では意欲の高さがうかがえた世帯が，実際の生活においては節約 行為をとる，もしくは行為の継続までには至らなかったことを意味 しているものと考えられる。

そこで本章では，節約行為の項目ごとに異なっていたグループを 再整理し, 節約行為の実行度に応じた世帯分類から行動に至る背景 となる意識的側面を検討する。具体的には, 表 2 で示した分散分析 において $10 \%$ 水準で有意だった 5 項目の回答状況に応じて注鋉 2 , 現状維持(高実行度)傾向にある世帯を「Gr.1(n=26)」, 節約意欲向上 傾向にある世帯を「Gr.2(n=20)」, 現状維持(低実行度)傾向にある世 帯を「Gr.3(n=24)」として分類し, 増減率・節約行為平均実行度・ 検針值から各グループの特徵を把握したうえで，意識項目との関連 分析から行動に至った背景について考察する。

\section{1 各グループの特徵}

グループ平均増減率と節約行為平均実行度を図 9 に, 各グループ におけるシステム設置前後の年積算検針值を図 10 に示す。併せて, それぞれの検定結果を表 3 , 表 4 に示寸。

まず，節約行為平均実行度についてみると，Gr.1 および Gr.3 は 現在と将来の差が小さいが, 前者は実行度が高く, 後者は低い。ま た，Gr.2 は現在と将来の差が大となっている。前述のとおり，世帯 の分類には節約行為の 5 項目のみを用いて行っているが，節約行為 全 33 項目の平均実行度においても, その特徴と対応していること が確認できる。 


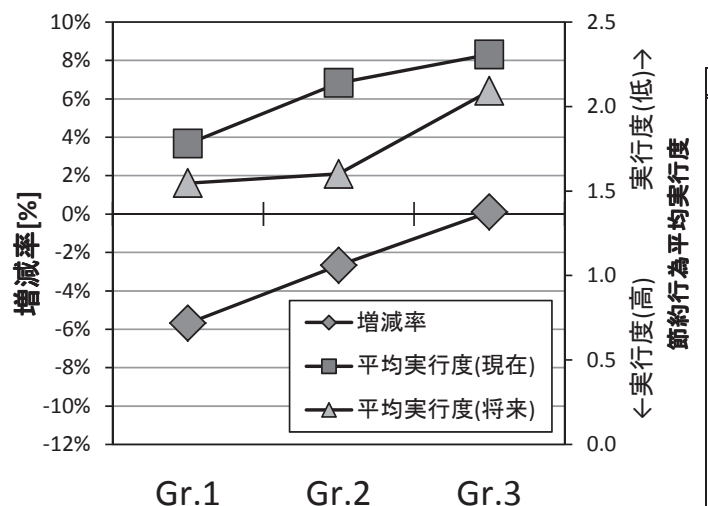

図 9 各グループの平均増減率・平均実行度

表 3 分散分析検定結果

\begin{tabular}{l|l|l|l|}
\hline アイテム & カテゴリ-1 & カテゴリ-2 & 検定結果 \\
\hline
\end{tabular}

\begin{tabular}{|c|c|c|c|c|}
\hline \multicolumn{2}{|l|}{ 増減率 } & \multicolumn{2}{|c|}{ 分散分析結果 } & \multirow{2}{*}{ *** } \\
\hline & \multirow{3}{*}{ 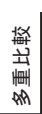 } & \multirow[t]{2}{*}{ Gr. 1} & Gr. 2 & \\
\hline & & & Gr. 3 & *** \\
\hline & & Gr. 2 & Gr. 3 & \\
\hline \multicolumn{2}{|c|}{ 平均実行度 } & \multicolumn{2}{|c|}{ 分散分析結果 } & *** \\
\hline \multirow{3}{*}{ （現在） } & \multirow{3}{*}{ 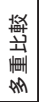 } & \multirow{2}{*}{ Gr. 1} & Gr. 2 & $* * *$ \\
\hline & & & Gr. 3 & *** \\
\hline & & Gr. 2 & Gr. 3 & \\
\hline \multicolumn{2}{|c|}{ 平均実行度 } & \multicolumn{2}{|c|}{ 分散分析結果 } & $* * *$ \\
\hline \multirow{3}{*}{ （将来） } & \multirow{3}{*}{ 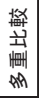 } & \multirow[t]{2}{*}{ Gr. 1} & Gr. 2 & \\
\hline & & & Gr. 3 & *** \\
\hline & & Gr. 2 & Gr. 3 & $* * *$ \\
\hline
\end{tabular}

***: $1 \%$ 水準で有意, $* *: 5 \%$ 水準で有意, $*: 10 \%$ 水準で有意

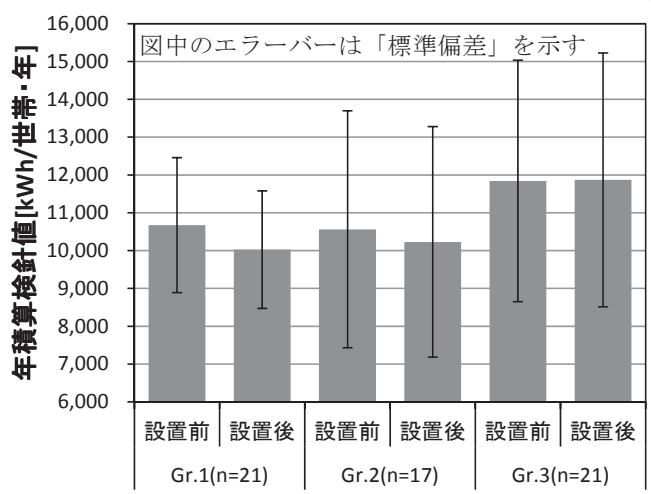

図 10 年積算検針值の比較

表 $4 \mathrm{t}$-検定, 分散分析検定結果

\begin{tabular}{|c|c|c|c|c|}
\hline & アイテム & カテデリー1 & カテデ゙リー2 & 検定結果 \\
\hline 拉 & Gr. 1 & 設置前 & 設置後 & $* * *$ \\
\hline 渠 & Gr. 2 & 設置前 & 設置後 & $* *$ \\
\hline+ & Gr. 3 & 設置前 & 設置後 & \\
\hline
\end{tabular}

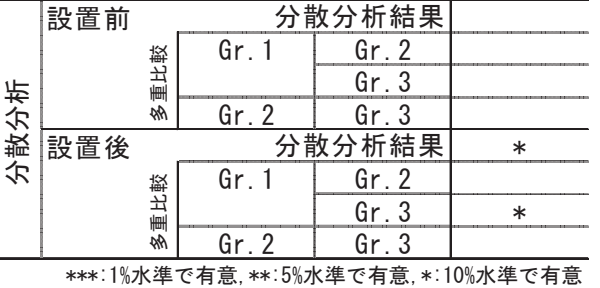

Gr.2 はシステム設置によって, 節約意欲が向上し, 将来の実行度 は Gr.1 とほぼ同程度となっているものの，増減率をみると Gr.1 ほ ぞ削減されていないことがわかる。これは, 前章の図 8 で示したカ テゴリースコアの結果と概ね対応している。

続いて，年積算検針值に着目寸ると，設置前と設置後の比較にお いて, 削減大であった Gr. 1 で $1 \%$ 水準, Gr. 2 で $5 \%$ 水準の有意差が
表 5 クロス集計結果

\begin{tabular}{|c|c|c|c|c|c|c|c|}
\hline アイテム/カテゴリー & \multicolumn{2}{|c|}{ Gr. 1} & \multicolumn{2}{|c|}{ Gr. 2} & \multicolumn{2}{|c|}{ Gr. 3} & \\
\hline a)モニター申込みの動機 & 度数 & 割合 & 度数 & 割合 & 度数 & 割合 & 度数計 \\
\hline 光熱費を削減したかった & 9 & $34.6 \%$ & 14 & $73.7 \%$ & 6 & $25.0 \%$ & 29 \\
\hline 電気料金を詳細に把握・管理 & 16 & $61.5 \%$ & 5 & $26.3 \%$ & 17 & $70.8 \%$ & 38 \\
\hline その他 (C02削減等) & 1 & $3.8 \%$ & 0 & $0.0 \%$ & 1 & $4.2 \%$ & 2 \\
\hline 計 & 26 & $100.0 \%$ & 19 & $100.0 \%$ & 24 & $100.0 \%$ & 69 \\
\hline b)最も多く利用した人の年齢 & 度数 & 割合 & 度数 & 割合 & 度数 & 割合 & 度数計 \\
\hline 39 歳以下 & 15 & $57.7 \%$ & 11 & $57.9 \%$ & 9 & $37.5 \%$ & 35 \\
\hline 40歳代 & 7 & $26.9 \%$ & 3 & $15.8 \%$ & 13 & $54.2 \%$ & 23 \\
\hline 50歳以上 & 4 & $15.4 \%$ & 5 & $26.3 \%$ & 2 & $8.3 \%$ & 11 \\
\hline (2) & 26 & $100.0 \%$ & 19 & $100.0 \%$ & 24 & $100.0 \%$ & 69 \\
\hline c) システムの利用頻度 & 度数 & 割合 & 度数 & 割合 & 度数 & 割合 & 度数計 \\
\hline 5日に1回以上 & 11 & $42.3 \%$ & 6 & $31.6 \%$ & 7 & $29.2 \%$ & 24 \\
\hline 1〜2週間に1回程度 & 12 & $46.2 \%$ & 9 & $47.4 \%$ & 9 & $37.5 \%$ & 30 \\
\hline 1ヶ月に1回程度，利用していない & 3 & $11.5 \%$ & 4 & $21.1 \%$ & 8 & $33.3 \%$ & 15 \\
\hline 計 & 26 & $100.0 \%$ & 19 & $100.0 \%$ & 24 & $100.0 \%$ & 69 \\
\hline (d) システム設置による環境意識変化 & 度数 & 割合 & 度数 & 割合 & 度数 & 割合 & 度数計 \\
\hline 強く意識し，生活が変化 & 9 & $37.5 \%$ & 7 & $38.9 \%$ & 6 & $28.6 \%$ & 22 \\
\hline 意識のみ & 11 & $45.8 \%$ & 9 & $50.0 \%$ & 11 & $52.4 \%$ & 31 \\
\hline 以前と変わらない & 4 & $16.7 \%$ & 2 & $11.1 \%$ & 4 & $19.0 \%$ & 10 \\
\hline 計 & 24 & $100.0 \%$ & 18 & $100.0 \%$ & 21 & $100.0 \%$ & 63 \\
\hline 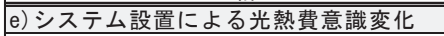 & 度数 & 割合 & 度数 & 割合 & 度数 & 割合 & 度数計 \\
\hline 強く意識し，生活が変化 & $\frac{125 x}{8}$ & $33.3 \%$ & $\frac{12 x+8}{8}$ & $44.4 \%$ & $\frac{12 x}{5}$ & $23.8 \%$ & 21 \\
\hline 意識のみ & 14 & $58.3 \%$ & 9 & $50.0 \%$ & 13 & $61.9 \%$ & 36 \\
\hline 以前と変わらない & 2 & $8.3 \%$ & 1 & $5.6 \%$ & 3 & $14.3 \%$ & 6 \\
\hline (1) & 24 & $100.0 \%$ & 18 & $100.0 \%$ & 21 & $100.0 \%$ & 63 \\
\hline f) 期待する削減光熱費 & 度数 & 割合 & 度数 & 割合 & 度数 & 割合 & 度数計 \\
\hline $500 \mathrm{P} /$ 月未満 & 11 & $45.8 \%$ & 6 & $33.3 \%$ & 7 & $33.3 \%$ & 24 \\
\hline $500 \mathrm{円} /$ 月 999円/月 & 9 & $37.5 \%$ & 5 & $27.8 \%$ & 5 & $23.8 \%$ & 19 \\
\hline $1,000 \mathrm{~m} /$ 月以上 & 4 & $16.7 \%$ & 7 & $38.9 \%$ & 7 & $33.3 \%$ & 18 \\
\hline わからない & 0 & $0.0 \%$ & 0 & $0.0 \%$ & 2 & $9.5 \%$ & 2 \\
\hline me & 24 & $100.0 \%$ & 18 & $100.0 \%$ & 21 & $100.0 \%$ & 63 \\
\hline g) 目標とする削減光熱費 & 度数 & 割合 & 度数 & 割合 & 度数 & 割合 & 度数計 \\
\hline $1,000 \mathrm{P} /$ 月未満 & 11 & $45.8 \%$ & 7 & $38.9 \%$ & 5 & $23.8 \%$ & 23 \\
\hline $1,000 \mathrm{円} /$ 月 1, 999 円/月 & 12 & $50.0 \%$ & 6 & $33.3 \%$ & 7 & $33.3 \%$ & 25 \\
\hline $2,000 \mathrm{~T} /$ 月以上 & 1 & $4.2 \%$ & 5 & $27.8 \%$ & 8 & $38.1 \%$ & 14 \\
\hline わからない & 0 & $0.0 \%$ & 0 & $0.0 \%$ & 1 & $4.8 \%$ & \\
\hline 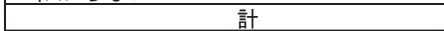 & 24 & $100.0 \%$ & 18 & $100.0 \%$ & 21 & $100.0 \%$ & 63 \\
\hline 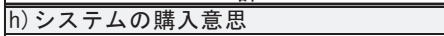 & 度数 & 割合 & 度数 & 割合 & 度数 & 割合 & 度数計 \\
\hline 購入する & 19 & $79.2 \%$ & 12 & $66.7 \%$ & 12 & $57.1 \%$ & 43 \\
\hline 購入しない & 5 & $20.8 \%$ & 6 & $33.3 \%$ & 9 & $42.9 \%$ & 20 \\
\hline 計 & 24 & $100.0 \%$ & 18 & $100.0 \%$ & 21 & $100.0 \%$ & 63 \\
\hline i）普段の光熱費について & 度数 & 割合 & 度数 & 割合 & 度数 & 割合 & 度数計 \\
\hline 多い & 2 & $7.7 \%$ & 1 & 5. $0 \%$ & 7 & $30.4 \%$ & 10 \\
\hline やや多い & 6 & $23.1 \%$ & 6 & $30.0 \%$ & 8 & $34.8 \%$ & 20 \\
\hline 普通・変わらない & 11 & $42.3 \%$ & 10 & $50.0 \%$ & 6 & $26.1 \%$ & 27 \\
\hline やや少ない & 6 & $23.1 \%$ & 3 & $15.0 \%$ & 2 & $8.7 \%$ & 11 \\
\hline 少ない & 1 & $3.8 \%$ & 0 & $0.0 \%$ & 0 & $0.0 \%$ & 1 \\
\hline 計 & 26 & $100.0 \%$ & 20 & $100.0 \%$ & 23 & $100.0 \%$ & 69 \\
\hline 地球温暖化などの環境問題に対する関心にこつて & 度数 & 割合 & 度数 & 割合 & 度数 & 割合 & 度数計 \\
\hline 非常に関心がある & 6 & $23.1 \%$ & 4 & $20.0 \%$ & 1 & 4. $2 \%$ & 11 \\
\hline 関心がある & 11 & 42. $3 \%$ & 12 & $60.0 \%$ & 11 & $45.8 \%$ & 34 \\
\hline やや関心がある & 9 & $34.6 \%$ & 4 & $20.0 \%$ & 12 & $50.0 \%$ & 25 \\
\hline あまり関心はない & 0 & 0 . & 0 & $0.0 \%$ & 0 & $0.0 \%$ & 0 \\
\hline 関心はない & 0 & $0.0 \%$ & 0 & $0.0 \%$ & 0 & $0.0 \%$ & 0 \\
\hline 計 & 26 & $100.0 \%$ & 20 & $100.0 \%$ & 24 & $100.0 \%$ & 70 \\
\hline k) 地球温暖化などの環境問題にこつて & 度数 & 割合 & 度数 & 割合 & 度数 & 割合 & 度数計 \\
\hline よく話をする & 2 & $7.7 \%$ & 2 & $10.0 \%$ & 0 & $0.0 \%$ & 4 \\
\hline 話をする & 4 & $15.4 \%$ & 4 & $20.0 \%$ & 5 & 20. & 13 \\
\hline 時々言 & 20 & $76.9 \%$ & 14 & $70.0 \%$ & 17 & 70. & 51 \\
\hline あまり話はしない & 0 & $0.0 \%$ & 0 & $0.0 \%$ & 0 & $0.0 \%$ & 0 \\
\hline 全く話はしない & 0 & $0.0 \%$ & 0 & $0.0 \%$ & 2 & $8.3 \%$ & 2 \\
\hline 計 & 26 & $100.0 \%$ & 20 & $100.0 \%$ & 24 & $100.0 \%$ & 70 \\
\hline 1) 世帯人数 & 度数 & 割合 & 度数 & 割合 & 度数 & 割合 & 度数計 \\
\hline 2 人以下 & 6 & $23.1 \%$ & 3 & $15.0 \%$ & 3 & $12.5 \%$ & 12 \\
\hline $3 \curlywedge$ & 6 & $23.1 \%$ & 4 & 20. & 5 & $20.8 \%$ & 15 \\
\hline $4 \curlywedge$ & 9 & $34.6 \%$ & 11 & $55.0 \%$ & 6 & $25.0 \%$ & 26 \\
\hline 5 人以上 & 5 & $19.2 \%$ & 2 & $10.0 \%$ & 10 & $41.7 \%$ & 17 \\
\hline 計 & 26 & $100.0 \%$ & 20 & $100.0 \%$ & 24 & $100.0 \%$ & 70 \\
\hline m) 妻の職業 & 度数 & 割合 & 度数 & 割合 & 度数 & 割合 & 度数計 \\
\hline 給与取得者 & 7 & $29.2 \%$ & 2 & $10.5 \%$ & 4 & $16.7 \%$ & 13 \\
\hline 主婦(職あり) & 8 & $33.3 \%$ & 4 & $21.1 \%$ & 10 & $41.7 \%$ & 22 \\
\hline 主婦(職なし) - 無職 & 9 & $37.5 \%$ & 13 & $68.4 \%$ & 10 & $41.7 \%$ & 32 \\
\hline Co & 24 & $100.0 \%$ & 19 & $100.0 \%$ & 24 & $100.0 \%$ & 67 \\
\hline
\end{tabular}

認められるものの, Gr.3 は差がない。また，グループ間の電力消費 量を比較すると, 設置前後ともに Gr.3 の消費量が大となっている。 特に設置後の Gr. 1 と Gr.3 の間に $10 \%$ 水準ながらも有意差がみられ, Gr.3 の節約行為の実行度の低さと対応している。ただし，後述する 表 5 の世帯人数において「5 人以上」が 4 割以上含まれていること も一因として考えられる。 


\section{2 意識項目との関連}

電力消費量の削減につながる行動を起こす背景となる要因につい て検討するため, 各グループにおける意識項目・世帯特性との関連 のクロス集計結果を表 5 に示す。

【Gr.1】は電気料金を詳細に把握・管理するためにシステムを導 入し, 支払ってもよいと思う価格で発売した場合, 多くが購入する 意思を示している。また, システムの利用頻度は高いものの, 期待 • 目標削減光熱費は低い。節約行為全体の実行度がシステム導入前か ら高く, 普段の光熱費も「やや少ない」「少ない」と回答する割合が 他のグループより高い傾向にあることからも, 日常生活から節約に 対して努力しており，システムの利用が光熱費削減に直結しないと 考えているものと思われ，過大な期待を寄せていないと考えられる。

【Gr.2】は光熱費削減を目的としてシステムを導入している世帯 の割合が高く, 設置によって光熱費に対して意識・生活が変化した 割合が若干多い。同様に, 環境に対する意識や生活の変化した世帯 がわずかながらも多くみられる。また, 環境問題に対する関心が高 く, 家族間の会話も多い。妻の職業をみると「主婦 (職なし) ・無職」 の割合が高いことからも，家事の従事時間が長いことが想定され， 光熱費削減・環境配慮型志向が強いといえる。

【Gr.3】は Gr.1 と同様に電気料金を詳細に把握・管理するために システムを導入しているものの, 購入には消極的な世帯の割合が若 干多い。また, 普段の光熱費が「多い」「やや多い」と感じている世 帯が多いため，システムによる期待・目標削減光熱費が高い。しか しながら, 生活が変化するまで喚起された世帯の割合が少ないこと から, 実際の利用頻度は低くなっている。世帯人数が他のグループ と比較して多いことも，削減に至らなかった一因と考えられる。

以上のことから，システム設置前から節約行為の実行度が高い世 帯は, システムを活用することにより, より光熱費が削減されたも のと考えられる。節約意欲が高い世帯は, システム導入を契機とし て，行動を起こそうとする意欲は高いが，実際の行動には直結しづ らく, 以前から実行していた世帯ほど削減には至らなかったものと 考えられる。意欲が低い世帯においても, システムの導入が動機付 けになることで，エネルギー削減効果が期待されたが，その効果は 顕著に現れなかった。これまで省エネに努めてこなかった世帯は節 電に関する具体的なノウハウがないことも, 削減されなかった要因 の一つと推察される。よって, 動機付けとなる本システムのような” 仕掛け”の投入のみでは直接的な削減効果を得るには不十分であり, システム導入前から日常生活において意識を向上させ, 節約行為を 習慣化させることによって, システムによる効果がより強く得られ るといえる。

\section{7. まとめ}

本研究では, 広島県広島市に所在する全電化住宅を対象として, 光熱費管理支援システムによって得られた測定データと検針值に基 づき, 居住者が自宅のエネルギー消費量を把握することによる電力 消費量削減効果について検討を行った。得られた知見について以下 にまとめる。

1）システム設置によるエネルギー削減効果について, 設置前後 1 年 間の検針值および気温の影響を除外した推定值による年積算電力
消費量を用いて検証したところ, 約 $3 \%$ のエネルギー削減効果が みられた。本研究で対象としたモニター住宅居住者は, 省エネに 対する意識がシステム導入前から高いことが予想されるため, シ ステム導入によっても大幅な削減はみられなかったものの, 全体 の 2/3 の世帯における削減が確認できたことを考えると, 本シス テムが喚起ツールとしての役割を果たしているものと考えられる。 2）全世帯における現在の節約行為の実行度をシステム設置後の予 想実行度と比較すると, 全ての項目において後者が上回っている ことから，システム設置を契機として節約行為が促される可能性 が示唆された。また, 節約行為の世帯平均実行度が高い世帯ほど 電力消費量が削減される傾向がみられたことから, 現在と将来の 実行度の変化に基づいて, 項目ごとに世帯を 3 分類し, 増減率の 差異について分散分析を実施した。その結果，暖冷房する時間や 期間を減らす，熱いものは常温で冷やしてから冷蔵庫に入れる， 洗濯機の使用時にまとめ洗いをするといった行為において，シス テム設置前から実行していた世帯がそうではない世帯よりも有意 に削減されていることがわかった。

3）電力消費量の増減に及ぼす影響要因を検討するため, 分散分析で 有意であった節約行為 4 項目を用いて数量化理論第 I 類による解 析を行った結果， 0.687 の重相関係数が得られ，全ての項目にお いて 0.3 以上の高い偏相関係数を示した。サンプル数に偏りがみ られた「使用していない部屋の照明は消寸」を除いて「現状維持(低 実行度)世帯」「節約意欲向上世帯」「現状維持(高実行度)世帯」の 順に削減率が高くなり，システム導入を契機として節約行為の促 進が期待された「節約意欲向上世帯」は，これまでも節約行為を 実施してきた「現状維持(高実行度)世帯」ほど削減されなかった。

4）普段から節約行為を実行している世帯(Gr.1)は，システムに対し て過大に期待していないものの，活用することにより電力消費量 が抑えられる傾向が認められ, 逆に, 節約実行度・節約意欲が低 い世帯(Gr.3)は，期待は高いものの利用頻度が低いことから，電 力消費に変化がみられなかった。一方, 節約意欲が高い世帯(Gr.2) は，光熱費削減・環境配慮型志向が強いものの，節約実行度は Gr.1 と比較して低く，大きな削減効果は現れなかった。よって， システムを活用する前から節電に効果的な行動などの知識を習得 させることによって,より強い効果が得られるものと推察された。

HEMS のようなシステムは, 省エネなどの節約行為を強いるもの ではなく, 居住者に自発的な行動を促すものであるため, ライフス タイルに無理のない節電方法として有効であると考えられる。 本研究の成果より, 削減効果の多寡には, 日常的な省エネ行動の 実践状況が大きく関わっていることから，システムを通して具体的 な省エネ行動を呈示するなど，情報提供に関するネット網の構築な どのツールを充実させることで，意識喚起が継続的に促され，より よい効果が得られるものと考えられる。

また，実際の国民レベルにおける節電対策として，本システムの ような機能を持つ設備を普及させるには, コスト面に課題を残して いることから，国や自治体による制度的な側面からの促進（法的整 備，導入や普及に関するガイドラインの制定，経済的支援など）が 有効であると考えられ，今後は官民の連携に向けた方策の構築が求 められる。 


\section{謝辞}

本研究は, 広島大学と中国電力株式会社との共同研究として行わ れたものである。本研究の遂行にご協力いただいた松永裕介氏 (当 時, 広島大学大学院生), 山成沙弥氏 (当時, 広島大学学生), 並び に, 調査対象住宅の皆様に感謝の意を表します。

\section{注}

注 1）モニター住宅は，「ガス」「灯油」をエネルギー源とする機器を使用し ていないことを条件として選定している。

注 2）電力消費量は 30 分間隔, $1 \mathrm{Wh}$ 単位の精度で測定されている。居住者は 専用の Web サイトを通して, 住宅全体と各自で選択した 10 系統それぞれ の電力消費量, 電気料金, $\mathrm{CO}_{2}$ 排出量について, 年 $\cdot$ 月 $\cdot$ 日・時間単位で 把握することが可能である。また， 1 ケ月の予測月額電気料金表示，シス テム導入前の電力消費量のデータ登録, 目標金額登録, 超過アラームメー ルなどの機能も利用できる。

注 3）「属性調查」は実施期間内に 1 回のみの実施であるが，「モニター調査」 はシステムの設置後, なるべく日を置かずに回答を得る必要から, 設置済 みの世帯から順に 50 件, 25 件, 25 件の計 3 回に分けて行っている。配布・ 回収方法は，「属性調査」では返信用封筒を同封した調查票を調查対象住 宅に郵送し, 回収も郵送により行い,「モニター調査」ではインターネッ 卜の専用ページで質問を提示し, 回答入力を求める形式で害施している。 なお, いずれも主婦の方, もしくは最も家事に慣れている方に記入を依頼 している。

注 4）システム設置月が世帯によって異なっているため, 設置前後の 1 年間の 期間にばらつきがある。例えば，設置最速世帯における設置前の 1 年間は $\lceil 2007$ 年 7 月 2008 年 6 月」, 設置後は「 2008 年 7 月〜 2009 年 6 月」と なり, 最遅世帯は「 2007 年 12 月 2008 年 11 月」と「 2008 年 12 月 2009 年 11 月」となっている。

注 5) 本研究におけるこれまでの成果 ${ }^{6)}$ により, 日積算電力消費量と日平均外 気温の間には二次曲線の関倸があることが明らかとなっているため, 二次 関数を採用した。

注 6) システム設置前後で年間日数が異なることから, システム設置前の 2 月 29 日の值は除外している。

注 7）節約行為として提示した 33 項目は,「空調」「厨房」「給湯」「その他」 の 4 用途に属する機器名称 (用途) ごとに低負荷ライフスタイルを示寸行 為として設定している。現在の実行状況（システム取り付け以前の状況を 記入）について「1)している」「2)ややしている」「3)あまりしていない」「4) していない」, 将来の予想実行状況については「1)していると思う」「2)や やしていると思う」「3)あまりしていないと思う」「4)していないと思う」 の 4 段階尺度で尋衩ており, 集計・分析にあたっては, それぞれ順に 1 か ら 4 の得点を付与している。

注 8) 再分類された各グループは, 持っている意味（ここでは, 表 2 で示した 5 項目のうち, 例えば, 「1」の「現状維持(高実行度)世帯」に多く属した 世帯は「現状維持(高実行度)傾向にある世帯」であるという意味) について 妥当性を保持しつつ, 後に続く関連分析のため, サンプル数に偏りがない よう考慮し，注釈表 2 のように決定した。
注釈表 1 相関係数行列

\begin{tabular}{|c|c|c|c|c|c|}
\hline $\begin{array}{r}\text { アイテム } \\
\end{array}$ & 暖冷房 1 & 暖冷房 3 & 冷蔵庫(4) & 洗濯機 1 & 明 (1 \\
\hline 【暖冷房(1)】 冷 (暖) 房する時間や期間を減らす & 1.000 & 0.592 & 0.135 & 0.224 & 0.126 \\
\hline 【暖冷房(3)】冷 (暖) 房の設定温度を高(低)めにする & 0.592 & 1.000 & 0.230 & 0.196 & \\
\hline 【冷蔵庫(4) 熱いものは常温で冷やしてから入れる & 0.135 & 0.230 & 1.000 & 0.169 & 0.246 \\
\hline 【洗濯機 (1】使用時にまとめ洗いをする & 0.224 & 0.196 & 0.169 & 1.000 & 0.396 \\
\hline 【照 明(1】使用していない部屋の照明は消す & 0.126 & 0.172 & 0.246 & 0.396 & 1.000 \\
\hline
\end{tabular}

注釈表 2 世帯分類方法注 8 )

\begin{tabular}{|c|c|c|c|c|c|c|c|}
\hline & \multicolumn{6}{|c|}{2 の数 } \\
\hline & & 0 & 1 & 2 & 3 & 4 & 5 \\
\hline \multirow{6}{*}{ 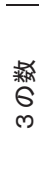 } & 0 & $5-0-0(15)$ & $4-1-0(4)$ & $3-2-0(6)$ & $2-3-0(6)$ & $1-4-0(2)$ & $0-5-0(0)$ \\
\hline & 1 & $4-0-1(2)$ & $3-1-1(5)$ & $2-2-1(3)$ & $1-3-1(1)$ & $0-4-1(0)$ & \\
\hline & 2 & $3-0-2(8)$ & $2-1-2(5)$ & $1-2-2(2)$ & $0-3-2(0)$ & & \\
\hline & 3 & $2-0-3(5)$ & $1-1-3(1)$ & $0-2-3(2)$ & & & \\
\hline & 4 & $1-0-4(2)$ & $0-1-4(0)$ & \multirow{2}{*}{\multicolumn{4}{|c|}{$\begin{array}{l}\text { 表中の「O-O-O」は「1の数－2の数ー-3の数」 } \\
\text { を示す。また（）内の数字は世帯数を示す。 }\end{array}$}} \\
\hline & 5 & $0-0-5(1)$ & & & & & \\
\hline
\end{tabular}

\section{参考文献}

1）森 敦子, 森山正和, 漆原 慎: エネルギー供給形態の異なる戸建住宅の エネルギー消費量と節約行為による省エネルギー効果に関する研究，日本 建築学会計画系論文集, No.565, pp.99-106, 2003.3

2) 水谷 傑, 井上 隆, 小熊孝典: 住宅内における用途別エネルギー消費と 住まい方の実態に関する研究 -アンケート調査に基づく分析一, 日本建 築学会環境系論文集, No.609, pp.117-124, 2006.11

3）湯淺和博，劉 正 賢，吉野博，長谷川兼一：低負荷型ライフスタイルに よる住宅のエネルギー消費量削減の可能性, 日本建築学会環境系論文集, Vol.74 No.642, pp.1019-1024, 2009.8

4) 石田建一, 佐藤 誠：HEMS による家庭用冷暖房・照明エネルギーの削 減効果の検証, 日本建築学会環境系論文集, No.595, pp.57-64, 2005.9

5）畑泰彦, 久和原裕輝, 太田真人, 須永修通: 環境エネルギー情報表示シス テムを備えた太陽光発電住宅における住まい手の意識と行動に関する研究, 太陽／風力エネルギー講演論文集 2010, pp.331-334，2010

6）松永裕介, 村川三郎, 西名大作 : 広島市の全電化住宅におけるエネルギー 消費実態に関寸る研究 その 1 対象住宅の属性と電力消費量の測定結果, 日本建築学会大会学術講演梗概集 D-2, pp.143-144, 2009.8

7）山成沙弥，村川三郎，西名大作，田中貴宏 他 2 名：広島市の全電化住宅 におけるエネルギー消費実態に関する研究 その 5 光熱費管理支援シス テムの導入による電力消費量削減効果, 日本建築学会中国支部研究報告集, 第 34 巻, pp.345-348, 2010.3

8）安藤元気, 村川三郎, 西名大作, 田中貴宏 他 2 名 : 広島市の全電化住宅 におけるエネルギー消費実態に関する研究 その 4 光熱費管理支援シス テムの導入による電力消費量削減効果, 日本建築学会大会学術講演梗概集 D-2, pp.1199-1200, 2011.8

9）安藤元気, 村川三郎, 西名大作, 折本和彦, 松永裕介 : 広島市の全電化住 宅におけるエネルギー消費実態に関する研究（第 4 報）居住者意識と電 力消費の関連分析, 空気調和・衛生工学会大会学術講演論文集, pp.537-540, 2011.9 